\title{
Vodun Continuum in Black America: Communication with the Dead and the Invisible World in Jesmyn Ward's Sing Unburied Sing
}

\author{
Fortuné AZON (Corresponding author) \\ University of Abomey-Calavi \\ GRAD (Laboratory of the Research Group on Africa and its Diaspora), Benin \\ E-mail: senakponazon@yahoo.fr
}

Received: September 12, $2021 \quad$ Accepted: October 11, $2021 \quad$ Published: October 13, 2021

doi:10.5296/ijch.v8i2.19001 URL: https://doi.org/10.5296/ijch.v8i2.19001

\begin{abstract}
The spread of Western rationalism through armed conquest, with the global dominance of Judeo-Christian and Islamic creeds, has almost obliterated the existence of the alternative ontological perceptions rooted in the dominated people's cultures. This essay studies how Ward's Sing Unburied Sing reaches back to African ancestral beliefs, vodun practices and rituals, and brings to life characters who strive to counteract exclusion with the conception of the world as a Whole, a continuum whose survival is premised on the respect of, and fusional union with, each element of that Whole. This conception partakes in the search for meaning to existence in a society that has erected individualism and the exclusion of black people into creed. The paper uses the theoretical approach of vodun ontology and, in an Afrocentric perspective, reads through Ward's novel this cultural trait thriving centuries after the enslaved people's departure from Africa. It purports to voice African traditional values and to celebrate cultural difference.
\end{abstract}

Keywords: vodun, connection, conjuring, ghost, suffering

\section{Introduction}

Yemaya Assessu, Assessu Yemaya, Yemaya Olodo, Olodo Yemaya: J'honore l'espace en toi où tout l'Univers réside. J'honore cet espace d'Amour, de vérité, de paix et de lumière en toi. Et quand tu es dans cet espace en toi et que je suis dans cet espace en moi, nous sommes Un. 
Sylvia Kramer

(A mantra dedicated to the Yoruba goddess mother of creation, childbirth and death, the Goddess of the Seven Seas, of Ancient wisdom, love, and healing and of the collective unconscious)

In the same way humans hunger for food and thirst for drink to sustain life in the body, our spirits may, as desperately, request the feeling of ecstasy which lies in the connection to a supreme, absolute source of beauty beyond description. We yearn for the fusion with a ravishing light which, depending on cultural and personal experiences, some people try to find in religious figures, in rituals, in contemplation, in arts, in eroticism, or in the use of psychoactive substances. The ecstasy of perfect connection to the whole of creation, bearer of this light, is what some vodun worshippers express in this mantra addressed to Yemaya, the Yoruba goddess.

The holistic fusional connectivity expressed in this chant to the deity of creation and the seas is at the core of vodun philosophy, as it is practiced in the coastal regions of West Africa, namely among the Adja-Tado people and the Yorubas, and in most locations of the African diaspora. To the celebratory individualism and self-reliance hailed in the Western tradition of liberal humanism (Emerson, 1985, p. 889-909), these people oppose holistic connectivity. This research paper identifies, in Jesmyn Ward's Sing Unburied Sing (2017) (Sing), this matrix of universal connection ingrained in vodun culture, as the controlling metaphor the author uses to pinpoint and denounce racism and black exploitation in the late twentieth-century American society. Using the theoretical framework of vodun ontology, this paper interprets, through Sing, the disruption of black ancestral customs of unity wrought by white bigotry. It also highlights African Americans' resort to black ancestral religious values as a way to make sense of life and cope with racism and exclusion in the contemporary American society.

\section{Concept Clarification and Literature Review}

The concept of vodun encapsulates the traditional spirituality of the people living in the coastal line of the Bight of Guinea, one of the major locations that has fed its populations into the transatlantic trade of enslaved black people. Vodun articulates the linking dot between the visible and the invisible worlds. Within vodun spirituality, Kakpo and Ananou (2018) observe, humans enter into relation with God "through the reverence of the divine energies contained in natural cosmic elements, and through the veneration of the dead" (p. 127). The word vodun, in the Fon language where it originates, evokes invisible spiritual forces and their worship, mystery, depth, purity, and source of life (Houessou-Adin, n.p.). Continuum, on the other hand, is an idea that refers to a set of homogenous constituents arrayed in such a way that adjacent elements are not perceptibly different from each other, but are with quite distinct extremes. The Cambridge dictionary defines continuum as "something that changes in character gradually or in very slight stages without any clear dividing points".

That image of continuum is seen in the various local hues that vodun worshipping has acquired over time, with the flexibility that characterizes this "folk religion" (Martin, 2012, 
p.18), in Africa and in the many locations where vodun faith and vodun-influenced worldviews have spread today in the diaspora. But first and foremost, the concept of continuum is meant here to describe the chain of life, connectivity, identity yet difference, and interdependence between all living beings, between nature and the living world. Continuum also refer to the bridge relating both sides of the gap of death which encode the vodun belief. In order to stress the continuum and express the unity ingrained in the vodun worldview, this paper has adopted the Fongbe spelling vodun to include all other spellings: vaudou, vodù, voodoo, vaudoun...

Vodun worshipping, whether in West Africa, Cuba, Haiti or Louisiana, sees in all creatures various branches of the same tree, a galaxy of adjacent and almost identical fragments, all constituent of a unique essence that they may express in various ways. This intricate relation between beings allows what Avolonto (2018) calls the "(re)consideration of oneself, either as an entity in a dialectical relation with 'another oneself,' or simply as the margin of 'the other that is not us" (p.13). The vodun worshipper's look places the self and the other on the same side of his/her subjectivity or conscience. As a matter of fact, one core belief of vodun philosophy is that each being is replete with tiny parts of all that exists, that we all make a whole divided in smaller units connected in perpetual reciprocal influences. The living, the dead, and the yet unborn, animals, plants, humans, things. Everything is endowed with a soul and is connected in most intricate and unexplainable ways.

Some of the main practices and rituals in vodun which are expressive of vodun worshippers' rejection of the usual rigid partitions and categorizations seen in Western thinking include ancestor veneration, spirit possession, divination, and conjuring. These religious concepts and practices can be formulated only in a meaning system that allows a fluid interpenetration of the past and the present, of the visible and the invisible. Anderson (2008) makes, in the American parlance, a difference between voodoo, which encapsulates the religion with its beliefs, rituals, deities on the one hand, and, on the other hand, hoodoo which, along the banks of the Mississippi river, most particularly in the city of New Orleans, designates the mastery and well informed manipulation of the spirits of nature's elements and principles for the aim of healing and harming: "Hoodoo [...] does not refer to a religion [...] it designates a body of magical beliefs, with little reference to deities and the trappings of religious worship. Practitioners generally limit their duties to telling fortunes, casting spells, and making charms for paying clients" (p. xi). This distinction Anderson makes also exists in the Adja-Tado communities' vodun traditions where a clear-cut distinction is made between the vodunnon (vodun priest) whose major social function is to preside over a divinity/deity and attend to its worship rituals, and the amanwato who uses his voodoo-inspired knowledge about the medical and esoteric virtues of plants and other natural elements, his $b o$, to attend to the practical needs of people who consult him/her, to heal and also to cast spells or hurt. Nevertheless, most vodunnons/babalawos (vodun priests) often play the two functions, even if amanwatos are not all vodunnons. These two poles, the core divinity worshipping and bo, work in tandem with a third pillar: divination. Divination enables humans to receive and interpret the will of vodun deities through a science called Fa/Ifa. According to Kakpo (2018), it is a system of divination, a cowryshell-, or kolanut-system through which vodun divinities, using the 256 odus/du that 
encapsulate all the possibilities in the language of the interpretation system, communicate their will to the babalawo or bokonon. Each deity has its own odu through which it manifests its presence but the deity of Eshu-Ilegbara/Legba-the-Trickster, the god of language, is said to control the junction, the site of communication between deities and humans (p. 10). Divination is basically put at use for the welfare of adepts. So, beside this purely religious expression that the voodoo system fulfils in mediating the sacred realm, it is notably the conceptual frame for the ethnomedicine of some West African and black diasporic communities, rooted in the daily necessity of people who "use their conjure skills to create a tolerable life within largely untenable circumstances" (Rasbold, 2019, p.i).

In the US, the voodoo/hoodoo framework is used, among African Americans, as a code or set of symbols for making sense of life and for dealing with suffering and hardships, disease and exclusion. "New Orleans Voodoo, Kenaz Filan (2011) notes, is [...] about working with the spirits to bring about changes on the material plane" (p.ii). The resort to African-originated spirituality to cope with the hurts of life, within the black communities of America, accounts for the keen interest African American writers take in using the voodoo framework, deities, and rituals in their arts. It is a conceptual space for the assertion of identity and empowerment. Vodun offers African American vodun (voodoo/hoodoo/vaudou) worshippers a relation to the spiritual, rooted in their own cultural heritage. It is in this vein that most African American female writers, Zora Neale Hurston, Toni Morrison, Toni Cade Bambara, and Jesmyn Ward, among others, anchor their works in the embrace of vodun spirituality. This research paper sees in vodun an affirmation of difference and empowerment, a set of cultural codes adopted by the black characters of Ward's fiction for understanding the world and for coping with life hardships. It uses the vodun framework to analyze characters, events, themes, plot and other narrative devices in Jesmyn Ward's Sing.

Sing is a story of survival, of connection, and cultural resistance in a Southern black family of the Mississippi Valley stricken by white exclusion and extreme poverty. It quilts a collective story alternately relayed by its various characters, including the ghost of a twelve-year old black prisoner: Richie. Jojo, a boy of thirteen years, follows his mother Leonie to Parchman state penitentiary with his younger sister Kayla to bring his father back home at the latter's liberation. As they wait in front of the prison, a ghost gets into their car and follows them back home, scenting the smell of Jojo's grandfather, Pop, in the boy's body odor. Richie's ghost is stuck at the prison, long years after the boy has died stabbed by Pop, the only person who has ever loved and cared for him. The latter stabs and kills Richie in a tight embrace to spare him the wardens' cruel blood-eagle execution after the boy's unsuccessful attempt to escape from Parchman. Years after, Pop's own son, Given, is killed in wanton violence by his white playmates. Léonie, Given's sister, then falls in love with Mickael, a white boy from the family of her brother's murderer. Mickael and Leonie give birth to Jojo and Kayla. Richie's vengeful and grieving ghost, in search for Pop, follows Jojo home and haunts the family as he cannot find his way into the afterlife. The ghost is intent on reconstructing the memory of his past destroyed by his traumatic experience in prison. The only thing he thinks he needs to find his way is to listen to Pop recount the story of his death. Like the hundreds of love-hungry black ghosts who heavily flutter and flap around in the neighboring cemetery woods, both Given and 
Richie's ghosts, tragically felled by white hate, heave and hover between life and death, unable to find the way of the final liberation. Kayla finally exorcises all the ghosts, striking up the blues song that raises the curtain for them to the afterworld. By the same token, their bedridden grandmother, the medicine-woman, also eases her way toward her ancestors.

\section{Of Voodoo, Connection, Home, and the Blues in Sing}

Most rituals and practices, in voodoo paradigm, enact the move toward connection: connection with the past, with fellow humans, the nature, animals, the invisible world of spirits, and ancestors. The locus for privileged connection is home. So both concepts of home and connection are probed, conflated, reinterpreted in Sing's narrative. For Richie's ghost, as an heir to slavery and a social pariah, the concept of home bears more than a single limited import. His sufferings as a restless, wandering ghost, testify to this manifold deprivation of home: home first as a restful and warmth-filled abode for the parentless child he once was: personal home; second, home understood as the country of unbiased social connections that all African Americans dream of but which they cannot find quite well in their country: the American land; and last, home as the ancestors and gods' resting place where his spirit can finally find the so much sought peace and comfort after a life of exile and exclusion: the Ginen.

Richie, as well as Pop, do not conceive of home as a soulless referent, an unconnected abode, a set of streets, a city, or a randomly chosen geographical location. He articulates the connection he views in the concept of home saying: "Home is about the earth. Whether the earth open up to you. Whether it pull you so close the space between you and it melt and y'all one and it beats like your heart. Same time. Where my family lived . . . it's a wall. It's a hard floor, wood. Then concrete. No opening. No heartbeat. No air" (Ward, 2017, p. 115). He describes home in terms of belonging, affective bonds, and acceptance by the land elevated to the status of a living being with whom one nurtures a harmony, mutual belonging. Mutual belonging and the feeling of safety shared with one's father, one's mother, one's siblings, spouse, children, and other loved ones, are what the concept subsumes. But Richie does not have any of these. The announcement of his death leaves his mother unmoved. So no soft feelings connect him to the place where his family lives. Poppy Z. Brite says our homes are the places that are in our blood, that take us in and that we take into ourselves, places that are more valuable than life (Filan, 2011, p. 54). Home therefore justly encompasses and determines our past and therefore our future, our identity and our destiny.

Richie's ghost traces back his understanding of home, as a privileged locus for connection, to his time in Parchman prison when he sleeps besides Pop who is the first and only person who has ever selflessly cared for him, protected him. It is paradoxical that the first solace of love and caring that Richie gets occurs to him in the hostile setting of prison. Thus, his definition of home is not so much the place as what amount of solace it does connote. All the beauty twinkling in Pop's rapturous description of the place he himself calls home, in fact, metonymically unveils what that place contains in terms of tenderness, of warmth, of safety, and of mutual care: "We got so much water where I'm from. It come down from the north in rivers. Pool in bayous. Rush out to the ocean, and that stretch to the ends of the earth that you 
can see. It changes colors... like a little lizard. Sometimes stormy blue” (Ward, 2017, p.120). The rivers that River describes twinkle with joy, comfort, and giving.

Richie's ghost is looking for River (Pop), his surrogate "big brother" and "father" (Ward, 2017, p. 85) presumably because in Richie's mind, home echoes with River who has opened his life to love and care, and additionally promised Richie to bring him to his own home, the geographical location where love, connection, is deployed to its fullest. Richie first identifies Jojo and connects him to River thanks to the privileged bond the ghost sees between the two young siblings (Jojo and Kayla), while Jojo lovingly tends to Kayla who is sick. The ghost sees home, connection in this love and longs for it. It is hence natural that he connote home to River as he is hungry for that solace of love and protection that only the latter has ever given him and that his descendants can give one another. It is this "scent" of love, and more particularly, of home that Richie identifies in Jojo and connects him to Pop although he has never seen Jojo before. "I followed the scent to him, he says, the dark, curly-haired boy in the backseat.... the scent of leaves disintegrating to mud at the bottom of a river, the aroma of the bowl of the bayou, heavy with water and sediment and skeletons of small dead creatures, crab, fish, snakes, and shrimp" (Ward 2017, p. 84).

Home as connection, and home as location whose scent one bears, are combined and arouse Richie's senses to envy. In this respect, Richie resonates with all the resentment and envy lying in Morrison's blooming but barren character Florens who complains, saying: "Mothers nursing greedy babies scare me" $(2009$, p. 8$)$. Florens, obviously, shuns the grace and radiance of the perfect nursing mother-suckling baby connection out of envy. The scene scares her because she herself cannot have a baby. In the same way, love dazzles Richie's imagination with the radiance of a gift his short life has not much spoiled him with, but whose sublimity he nonetheless feels and yearns for.

Love bonding, which is assigned an even higher value in the vodun worldview of Sing, is turned into a major sense of perception with which the ghost identifies people. Instead of the commonest senses of perception of touch, sight, smell, and taste that put humans in contact with their environment, which enable them to appraise colors, temperature, distance, and shapes, Richie's perception translates his surrounding into measurements or potential of love/connection that individuals and places are endowed with. The ghost's unawareness of the presence of Leonie, Pop's only child nearby, corroborates this interpretation. Leonie is known to have an arid heart uninhabited by giving, a heart dry of love and caring, other than for her strange, compulsive, and devouring infatuation with her companion Michael. Nonetheless, the ghost instantly spots Leonie's two children that he connects to River. This elemental identification which can spot moral qualities in people and track the "scent" of love in bloodline articulates one of voodoo's royal beliefs.

Vodun, in fongbe where the lexeme originates, is also called hun, whose first and denoted meaning is blood, and from which words such as hunkpamin, hunvi, hungan, and hunnon, which respectively mean vodun convent, young initiate, experienced adept or priest, and priest, are derived. The lens of perception of reality that the ghost shows allows us for a totally different link and identification of the self and of the other, a different nature of the ties 
between beings. Why does Richie's ghost first spots Jojo while he takes no heed of Leonie, Pop's closest relative present? And why does he feel closer to Pop than he does to his own blood family? The links expressive of vodun paradigm that Ward seems to extol and that the ghost spots in the blood of the beings he feels close to are love and kindness, positive feelings, good nature or character, rather than biological relationships, contrary to the usual parameters of kinship. The connection is made through the assumption that all entities, whether animals, trees, or houses, are endowed with a spirit which may be benevolent or malevolent. The other is endowed with such a spirit to which one may be connected through similar propensity (good or bad), or sheer will of one's spirit and the mind.

Pop asserts that he somehow makes the trip with Jojo, Kayla and Leonie to Parchman, through his gris-gris bag. "it's the only way I could send a little of me [spiritually] with ya'll" (Ward, 2017 , p. 221). Some of nature's entities which, in most religions, are denied a spirit and usually ranked below the human being, in vodun belief, are put on par with human spirit and are even said sometimes to surpass our spirits in power: "spirit in everything. In the trees, in the moon, in the sun, in the animals... the sun is most important" (Ward, 2017, p.46). It is the knowledge and skillful manipulation of those overpowering natural forces which serves among vodunnons as yardstick to assess and demonstrate their levels of vodun konaissans.

Sing's vodun taxonomy takes root in the obvious characteristics of the goofer's ingredients. In the protection gris-gris bag that River gives his grandson Jojo for the trip, he puts a woodpecker's feather symbolizing lightness, a piece of rock for solidity, and a boar's tusk that stands for the animal's strength. The connection to the spirit and forces of the rock, the bird, and the boar will enable the amulet wearer to borrow from the characteristics embodied in these entities for a better balance: "Everything got power...there's spirit in everything. In the trees, in the moon, in the sun, in the animals. [...] But you need all of them, all of that spirit in everything, to have balance" (Ward, 2017, p.46).

Balance is of paramount importance since the knowledge of these esoteric combinations of forces forbids abuse. Taking too much for the worshipper's own advantage may create an imbalance somewhere else. This unwanted consequence brings vodun initiates to mind and care for the whole continuum: "No waste, River says. Waste rots. Too much either way breaks the balance" (Ward, 2017, p.46). One should not indulge oneself with more than the minimum necessary. This respect of each component of the nature, and also blood relations which allow family hereditary gifts, are the requisite for the ebb and flow of the rootworker's conversations with plants, animals, and the invisible world. Heredity and nature respect empower vodun priests, initiates, and otherwise naturally gifted people to the second sight that gives them access to the invisible world of spirits. It is this gift that Jojo and Kayla are endowed with. Jojo finds it impossible to ignore the animals around him speaking to him: "it was impossible to not hear the animals...I looked at them and understood, instantly, and it was like looking at a sentence and understanding the words, all of it coming to me at once" (Ward, 2017, p. 9).

In Sing, the failure for black characters to embrace vodun spirituality, which is the articulation of the self as part of a larger continuum, proves detrimental to their psychological balance. This denial results into insanity as the case of Stag, Pop's elder brother, evidences. It may also result 
into drug addition, as with Leonie. Only the bulwark of konaissans or acceptance of, and connection to, lè mistè helps them cope with the hardships of exclusion. In addition to the full connection with ancestors that gives the assurance of a life after life, Pop, Mama, and Jojo enlarge the scope of their bonds to animals, plants, and things. Mama, as a root worker, nourishes a special connection with plants and hears them reveal to her their curing virtues, which she later tries to teach her daughter Leonie, but without success.

The passage which describes the ghost's failure to find his way to the afterworld is one of these passages where the story reaches its purest expression of vodun esthetics, translating in West African-originated spirituality the social wounds of black people. The narrative turns into a mirror that presents the American society with its own ghosts which keep on piling up by virtue of, and reverence for, the traditions and customs, the laws and decrees which create and nurture islands of hell in paradise, hunger in the land of plenty. Those ghosts that the American society has to confront are here showcased by the twelve year-old boy, Richie, the silhouette of a war-stricken country child, "big head shaped like an onion, the kind of head seemed too big for his body: a body all bones and skin" (Ward, 2017, p.15). Parchman, the former plantation with enslaved Blacks, is now turned into a prison, a change of institutional profile which alters nothing of the single social function that Parchman [note its near homophony with "parched man"] has ever played: an instrument of exploitation, torture and deprivation, a place where white people flog and "work" black people.

After Richie's death, Parchman plumbs his rise and journey to the afterlife. He is limbo, hovers low in the liminal place between the two worlds, in a nightmarish exertion.

There was no warmth or cold there, he says. Walking was like swimming through tepid gray water. I paced in circles. I don't know why I stayed in that place, why every time I got to the edge of the young stand [...], rounded and darkened, draped with a web of green thorny vines, I turned and walked back. In that day that never ended, I tried to remember how I got there. (Ward 2017, p. 84.)

The memories of his tormented soul are memories of hunger, of chain and flogging. But contrary to this ghost, Given's ghost, when he appears to his family members who are endowed with second sight, looks peaceful and even protective at times, going as far as to become Leonie's guardian when she starts sinking into drug addiction. But Given is loved, mourned and has a home while Richie is spoiled with none of these.

In picturing the inability of Richie's soul to find its way to the afterlife following a violent and traumatic death perpetrated out of love and protection but nevertheless out of constraint, and the return of a restless and tormenting ghost, Sing signifies on works such as Toni Morrison's Beloved. The restless murdered one, victim of the merciless society, cannot cross the bridge between two worlds and comes back to torment the loved ones. Sing nonetheless deploys its own vodun hermeneutics of the afterlife with the tableau of the ghost's interaction with the psychopomp deity, the flying horned serpent or dragon. The failed attempt of the divinity to lift and fly Richie into his original homeland allows however the latter to get a short glimpse into the edenic ancestral Duat, far across from water: 
It is green and hilly, dense with trees, riven by rivers. The rivers flow backward: they begin in the sea and end inland. The air is gold: the gold of sunrise and sunset, perpetually peach. There are homes set atop mountain ranges, in valleys, on beaches. They are vivid blue and dark red, cloudy pink and deepest purple. They are yurts and adobe dwellings and teepees and longhouses and villas. Some of the homes are clustered together in small villages: graceful gatherings of round, steady huts with domed roofs. And there are cities, cities that harbor plazas and canals and buildings bearing minarets and hip and gable roofs and crouching beasts and massive buildings that look as if they should collapse, so weirdly they flower into the sky. (Ward, 2017, p.153).

After this experience, the restless ghost mistakenly thinks that piecing together the various patches of his past life, disentangling the fragments jumbled in his memory, especially the circumstances of his own death, would bring him the necessary peace to fly away back home. But with Richie hearing the tale of how Pop has killed him, the trauma attached to the atrocity of his death resurfaces, loaded with the same intense pain which in the first place created the ghost's dissociative amnesia. The ghost now grows even more fidgety and threatening to River's family as he realizes he cannot make the crossover home with its promise of peace and harmony.

In contrast to the lofty vignette of home that River and his kin nurture, Leonie dreams of a narrower, consumerism-driven home, all conspicuous luxury, that she would inhabit only with her lover Mickael and two children:

I had an apartment in my head. Once we're on our feet we'll get to it, ... I only saw that place. I imagined us settling in one of the bigger towns on the Gulf Coast, in one of those three-story complexes with metal-and-concrete stairs leading from one level to another. We would have big whitewashed, carpeted rooms, and our little family have space, anonymity, and quiet. (Ward, 2017, p. 124).

The story all the same uncovers the barrenness of these luxurious dwellings where the excess of an egoistic pursuit of happiness chases love, laughter, and happiness away. It is this kind of home that prevents Mikael's parents from welcoming their son, their daughter-in-law and grandchildren after midnight. When the family gets back from Parchman prison, they have nowhere to go and knock at the door of Mickael's parents. But they are driven away. It is against such luxurious but pitiful homes, secluded and turned inwards, these homes full of hatred and venom for the outer world, that André Gide (2007) spits his invectives: "Familles, je vous hais! Foyers clos, portes renfermées; possession jalouse du bonheur : Families, I hate you! Closed homes, doors shut, jealous possession of happiness," because they know no giving, no outward connection. In exposing this spiritual poverty, the narrative partakes in the enterprise of heritage reviving and also, most importantly, it partakes in the psychological strategy of empowerment, roles that African American literature and music have always played. 
James Baldwin, in relation to his mission as an African American writer, called himself "a blues singer," performing with his pen the same social mission the artist singer fulfills. In his definition of the writerly blues singer, Baldwin hails bawdiness as one of the defining characteristics of the black artist bearing witness to the black experience in America and really using the English language rather than imitating Shakespeare and James Joyce (Thompson, 2017, n.p.). The breach of the Western sense of intellectual "decency" that Sing riffs on can be identified as the ghost conversation the novel initiates with what a Western rationalist epistemology might label, in a different conceptual framework, a magic realist grain. The conceptual frame of these interactions and dialogues are easily recognized and legitimated in an Afrocentric realistic vision without any appeal to the world of fables or fantasy. These interactions are believed to be part and parcel of everyday life. It is in this sense that Ward subverts the Western literary canon. The narrative is about a reappropriation and remaking of language to produce works and words of liberation. Jimi Hendrix (1968), understandably, sang: "Well, I stand up next to a mountain/ And chop it down with the back of my hand...Well, I pick up all the pieces and make an island / Might even raise just a little sand / 'Cause I'm a voodoo child / Lord knows I'm a voodoo child." Self-recognition in an ancestral paradigm different from Eurocentricity is an act of empowerment.

The blues tradition is central to the discursive development of Sing, a thread spun alongside vodun symbols. The blues inform the title of the novel and are set as the ultimate achievement that will free the numerous ghosts of Bois Sauvage. Richie's ghost insists that finding the song, the right blues song will free him and lead him home: "A song. The place is the song and I'm going to be part of the song... It's why you can hear animals, see things that ain't there. It's a piece of you. It's everything inside of you and outside of you" (Ward, 2017, p.115). The blues song is the synecdoche for the whole West African tradition. Sing borrows from the blues music many features, among which its lyricism, black humor, and narrators' relay pattern.

The narrative's link to the blues is not only in the lyricism that serves as background tune for the confrontation of each character's frailty and precariousness with the unsurmountable odds of life, or in the challenge of resorting to mojo hands and gris-gris bags to cope with the hardships that the black condition poses in the American society. Sing's discourse participates, with its own variant, into the long chain of the versions of "Stagolee"/"Stagger Lee" blues song. Storytelling and singing, back to West African tradition, were two intertwined attributes of the griot's job that Sing takes up. Stag, River's elder brother who goes insane, sings his bawdy and wild otherworldly blues, roaming the streets of Bois Sauvage in deep night: "Oh Stag-o-lee, why can't you be true? (Italics not mine)" (Ward, 2017 , p. 9). It takes some humor to face the chaos of life and that humor is usually found in the blues music which becomes "an artistic response" to that chaos (Martin, 2012, p.134).

\section{Of Conjuring and Healing in Sing}

A total dissociation of, or lack of relation between, material prosperity or physical health and spiritual well-being is a conception that will hardly pass with vodun adepts or in cultural areas where vodun is practiced. Material and physical conditions are usually viewed by most 
people in these cultures as the reflection of the state of the spirit. Any changes intended on the material plane first tackle the "spiritual body". Herbal healing and other medicines destined to cure physical health often first address or are accompanied by some rituals that focus on that invisible part of the human being which is believed to command and rule the physical body: the spirit. This spiritual dimension of vodun practices which usually, instead of exclusively administrating medicines, plants' active substances to directly address the ailments of the body, first and foremost relies on the power of words (incantations, prayers), on secret combinations, rituals, and the forces of the nature to conjure to make spiritual impact on people in order to heal (or hurt/hex) their bodies or material lives, ultimately justifies the great stress root workers lay on their relations with deities, spirits and other natural forces. One belief ingrained in the cultural areas where voodoo worship is widespread is that everything has a spirit and that this spirit or principle is the real essence on which any desired change must be effected before one can produce effect on the physical plane. One caricatural assumption in such milieus which nonetheless articulates a facet of vodun culture is that no serious woe may betide anyone or an untimely death strike without an evil spirit or witchcraft hiding behind it. These suspicions would not be so widespread and omnipresent if it were not believed that one could summon and work on people's spirits to impact their health and material lives.

In Sing, the world of good and evil spirits and ancestors, elemental powers, mythic and colorful divinities, plot to create an island on which Mama Philomène reigns and on which she welcomes and helps the ailing people and black pregnant women of Bois Sauvage in need of assistance. Her craft, she has inherited by right of blood. It is obvious from the protagonists' outlook on life that in such an environment of adversity, the mastery of the art of healing is a map of the world which puts everything in its correct place, a system of belief that makes it easy for the black people to confront and tame the hardships of white hate and life contingencies. This accounts for Mama's insistence on teaching her daughter Leonie "spirit work" knowledge whose relevance the latter will not understand or accept: "She thought that if she taught me as much herbal healing as she could, if she gave me a map to the world (my emphasis) as she knew it, a world plotted orderly by divine order, spirit in everything, I could navigate it" (Ward, 2017, p. 50). In the logic of the story, Leonie feels all the pain of exclusion and poverty she does because she has failed in appropriating the empowering outlook that Chireau (2003, n.p.) calls theoretical and practical code which enables the black community to interpret and cope with suffering.

The mastery of the code is what, in fact, empowers Mama to help other ailing women and, finally, what gives her the mental strength necessary to confront the great pain of cancer. The same knowledge enables Kayla, the precocious heiress, to free the suffering and lost flocks of wandering ghosts in Given's forest to the hotep of the ancestors' abode, in the last conjuring ritual of the novel. Kameelah Martin, in her Conjuring Moments in African American Literature (2012), expounds this literary trope of improvised, biomythographic rituals that, in African American female fiction, works as a trigger to advance the plot toward its denouement. She articulates these rituals as "opportunities for growth and development": conjuring moments (p.6). The ending conjuring moment in Sing's narrative anoints little 
Kayla, the still inarticulate female toddler, as celebrating priestess with the otherworldly power of healing wounded souls. Kayla lifts the veil shrouding the way into the afterworld, and ushers her cancer-stricken grandmother and other restless dead ones into the realm of eternal peace. In straight line after the historical figures of Tituba and Marie Laveau, Kayla rises as an heiress to the matriarchal legacy of conjuring vodun queens. In choosing this female toddler for the task of healing the "tribal soul," Ward theorizes on her own [African] ancestral system of belief to create a discourse for identity construction. The narrative is a site for the re-creation of identity. This black family, especially its female folk, would perish, they could not even exist as a people, let alone as book characters, if they were deprived of this konnaissans which substantiates and frees them from the straightjacket of Christianity and, furthermore, signifies on American patriarchal institutions.

Sing presents us with two conjuring moments, both of which are toward the end of the story. The first occurs when Leonie gathers tombstones and grave dust for the veil lifting ritual of Maman Brigitte, the mistè mother of the dead. It helps Mama Philomène meet her deceased son Given and get the two of them into the afterlife. But Richie's ghost once again fails in finding his way to the Ginen. The second conjuring moment takes place in the backyard in the cluster of the trees Mama has planted each year in mourning her son killed by his white mates. This backyard hosts all the hovering lost souls, including Richie's, who stand for all the victims of white hate. These "unburied ghosts" finally fly away, freed by the blues song Kayla [which means purity] sings. One aspect capital to note is that the wandering spirits that crawl on these trees inhabit a place of mourning. The trees have been watered with a bereaved mother's tears. They are trees of sorrow planted by Mama Philomène grieving over her son come too late and departed too early in tragic circumstances expressive of racial tension. In this token, these woods bear the same negative spiritual charge with Parchman prison. The place is stained with blood, tears, torn flesh, and blossoming hopes and promises suddenly gone dead. Kayla, the little toddler, has received no initiation from anyone but is able to open the veil and help the lost souls find their way into the afterlife.

The final liberation through the ritual of blues song conjuring sets the décor for the final reconciliation within the family, between the dead and the living, the reunion of mother and son, of forsaken child lost to prison and ancestors. It most significantly engages the reconciliation between mother and daughter, the redemption of an irresponsible and unresponsive daughter [Leonie] whose change of heart her mother has always wished for. It is also a fulfilling time of reckoning. The blues song sets the rhythm for the unburied to be able to sing and therefore find the way back home. For Richie's ghost, it serves as trope for claiming his Africanity. His musical legacy is not only a marker of identity but identity itself, the signified that the boy's ghost merges with. "I could. Become. The song", he says (Ward, 2017, p. 186). Understandably, as he has forgotten the song, he gets lost. This is the song that he travels distances to find. If the musical notes of the song frees him while he is looking for his story, it means that the story is embedded in the song. As a matter of fact, the blues notes incorporate the painful history of African Americans. His self-identification with the song compares well with Mama Philomène's proud claim of divine lineage that stands somewhere between panegyric and incantation: "Je suis la fille de l'océan, la fille des ondes, la fille de 
l'écume [Yemayá]: I am the daughter of the ocean, the daughter of the waves, the daughter of the scum" (Ward, 2017, p.100). The two characters forcefully spin their identity tales in the empowering language of black culture and spirituality. The songs and the ocean divinity, tropes of identity, actuate the closeness to ancestral home and put the black person into control. The lineage with the ocean water turned complicitous reverses the pattern of captivity of the transatlantic crossing to the West. Dying, for Mama, is going back home through that water. She asserts before she dies: "I want to walk out the room. Walk out the front door. Walk straight to the bayou, to the water, step on it, shimmering glass under my soles, and walk until I disappear over the horizon" (Ward, 2017, p.137).

The discourse works almost exclusively in the sphere of black spiritual heritage, handling characters that cope with pain by rendering experience in terms of relationships with, and dependance on, the invisible. This dimension of the invisible world which surrounds us, most closely wraps us, yet remains unseen, the intertwining of this world with the visible world our bodies inhabit is what Birago Diop (1960) celebrates in Souffles: "Ceux qui sont morts ne sont jamais partis:/Ils sont dans l'Ombre qui s'éclaire/ Et dans l'ombre qui s'épaissait./ Ils sont dans le Bois qui gémit,/ Ils sont dans l'eau qui coule,/ Ils sont dans l'eau qui dort,/ Ils ont dans la Case, ils sont dans la Foule : Les Morts ne sont pas morts". [Those who are dead are never gone:/They are in the Shade that clears/ And in the shade that darkens./They are in the Woods that wails,/They are in the water that runs,/ They are in the still water,/They are in the Hut, they are in the Crowd: The Dead are not dead" (Translation mine)]

These narratives of identity provide the self with a simulacrum [in the sense of Baudrillard, that is signs, symbols, and simulations that are treated as and become reality], a new map that the self strives to fill and fit in. Ishmael Reed (1970) justly observes in this vein that "every artist is a priest" (Gale, 1988), a religious imaginer that creates new rituals, new collective perspectives preached and popularized through art. The artist tries to convert his/her people to these new dreams and visions. In the collective memory, these figures created by artists, the likes of Morrison's Pilate, Naylor's Mama Day, or Butler's Anyanwu, have a better hold on the public mind than real historical figures of vodun priests like Marie Laveau and Dr. John. Even these real historical figures need to be reinvented and celebrated through the works of artists before they can escape oblivion and be passed down to later generations. It is to the point to remind of Derek Walcott's quotation that Ward puts in epigraph to her novel: "The memory is a living thing - it too is in transit" (2017, p.ix). Memory is constant renewal. It is at the image of these vodun queens, spotlighted by African American writers, that Kayla, in Sing, gets crowned for, for the final liberating conjuring ritual:

Kayla raises one arm in the air, palm up ... but the ghosts don't still, don't rise, don't ascend and disappear. They stay. So Kayla begins to sing, a song of mismatched, half-garbled words, nothing that I can understand... And the ghosts open their mouths wider and their faces fold at the edges so they look like they're crying, but they can't. And Kayla sings louder. She waves her hand in the air as she sings... Kayla sings, and the multitude of ghosts lean forward, nodding. They smile with something like relief, something like remembrance, something like ease....Home, 
they say. Home. (Ward, 2017, p. 179)

\section{Conclusion}

One of the most manifest consequences of centuries of Western cultural and religious domination, political imperialism, and systemic brutal enslavement of African-descended people in the Americas, is the quasi-unanimous renunciation of African traditional faiths among contemporary black people, especially among the upwardly mobile elite. To better dominate, Westerners have posited Christianity as the supreme religion. But some black artist singers and writers have self-assigned the mission of reappropriating the African religious heritage in their art. Jesmyn Ward's Sing is one of those literary works that excavate and reinterpret African vodun tradition in the light of African Americans selfhood, suffering, and empowerment. This reading of Jesmyn Ward's Sing Unburied Sing that explores the adoption of ancestral vodun beliefs and rituals, among the masses of poor African Americans, sees the novel as tool of identity expression, a tool for social and spiritual empowerment. The artistic rendering of the vodun continuum subverts the concepts of identity, alterity, racial differences, and above all, the difference that separates humans from other entities. It stands as a distinct voice that celebrates connection and unity, speaking in defiance of the Western domineering metanarratives.

\section{References}

Anderson, J. E. (2008). Hoodoo, voodoo, and conjure, A Handbook. Greenwood.

Avolonto, A. (2018). Heuristic on vodun: "Alterity from within". Jogbe, the review of humanities: Toward a heuristic of research on vodun, 1(1), 13-17.

Barry, P. (1995). Beginning Theory: An Introduction to literary and cultural theory. Manchester University Press.

Baudrillard, J. (1994). Simulacra and simulation. University Michigan Press. https://doi.org/10.3998/mpub.9904

Baym, N., Gottesman, R., L. Holland, B., Murphy, F., Parker, H., Pritchard, W. H., \& Kalstone, D. (Eds.). (1985)

Butler, O. (1999). Wild seed. Warner Books.

Cambridge International Dictionary of English. (1995). Cambridge University Press.

Chireau, Y. P. (2003). Black magic: Religion and the African American conjuring tradition. University of California Press. https://doi.org/10.1525/california/9780520209879.001.0001

Diop, B. (1960). Souffles. Leurres et lueurs. Présence Africaine.

Emerson, R. (1985). Self-reliance. In Baym, N. (Ed.), The Norton anthology of American literature (Vol. 1., 2nd ed.). New York: W. W. Norton.

Filan, K. (2011). The New Orleans voodoo handbook. Destiny.

Gale, S. H. (1988). Encyclopedia of American humorists. Routledge. 
Gide, A. (2007). Nourritures terrestres. NP: Ebooks libres et gratuits.

Hendrix, J. (1968). Voodoo Child. Electric ladyland. Universal Music Publishing Group, Sony.

Houessou-Adin, T. (2009). Vodou in Benin. In Asante M. K., \& Mazama A. (Eds.), Encyclopedia of African Religion (pp. 691-694). Los Angeles: Sage.

Kakpo, M. (2018). Brief Hermeneutics of Jogbe. Jogbe, the review of humanities: Toward a heuristic of research on vodun, 1(1), 10-11.

Kakpo, M., \& Ananou, B. (2018). Sense and function of names in vodun: an anthroponymy of Sakpata initiates with the Fons. Jogbe, the review of humanities: Toward a heuristic of research on vodun, 1(1), 123-142.

Kramer, S. (2020, September 25). The Heart to heart connection: La Communication Animale. Retrieved from http://www.communication-animale-sylvia-kramer.be/430461732Blog

Martin, K. L. (2012). Conjuring moments in African American literature: Women, spirit work and other such hoodoo. Palgrave Macmillan. https://doi.org/10.1057/9781137336811

Morrison, T. (2004). Song of Solomon. Vintage International.

Morrison, T. (1987). Beloved. Knopf.

Morrison, T. (2009). A Mercy. Vintage.

Naylor, G. (1988). Mama day. Ticknor \& Fields.

Rasbold, K. (2019). Crossroads of conjure: The Roots and practices of granny magic, Hoodoo, Brujería, and Curanderismo. Llewellyn.

Thompson, C. (2017). Jimmy's Blues. The Los Angeles Review of Books. Retrieved from https://www.lareviewofbooks.org

Ward, J. (2017) Sing unburied sing. Scribner.

\section{Copyrights}

Copyright for this article is retained by the author(s), with first publication rights granted to the journal.

This is an open-access article distributed under the terms and conditions of the Creative Commons Attribution license (http://creativecommons.org/licenses/by/4.0/) 